\title{
Designing and Performance Evaluation of Biochar Production in a Top-Lit Updraft Upscaled Gasifier
}

\author{
Hussein Kisiki Nsamba1,2,3* , Sarah E. Hale ${ }^{4}$, Gerard Cornelissen ${ }^{4}$, \\ Robert Thomas Bachmann ${ }^{1}$ \\ ${ }^{1}$ Malaysian Institute of Chemical and Bioengineering Technology (MICET), Universiti Kuala Lumpur, Kuala \\ Lumpur, Malaysia \\ ${ }^{2}$ Section of Industrial Chemistry, Department of Chemistry, Makerere University, Kampala, Uganda \\ ${ }^{3}$ Invention Plus Limited, Kampala, Uganda \\ ${ }^{4}$ Norwegian Geotechnical Institute (NGI), Oslo, Norway \\ Email: ${ }^{\text {hnnsamba@cns.mak.ac.ug }}$
}

Received 29 January 2015; accepted 6 April 2015; published 10 April 2015

Copyright (C) 2015 by authors and Scientific Research Publishing Inc.

This work is licensed under the Creative Commons Attribution International License (CC BY).

http://creativecommons.org/licenses/by/4.0/

(c) $\underset{\mathrm{EY}}{\mathrm{i}}$ Open Access

\section{Abstract}

The Original Belonio Rice Husk Gasifier (OBRHG), initially of height of $0.6 \mathrm{~m}$, diameter of $0.15 \mathrm{~m}$ and thickness of $0.025 \mathrm{~m}$ was tested for biochar production through air gasification of rice husk $(\mathrm{RH})$ and the design was upscaled to height of $1.65 \mathrm{~m}$, diameter of $0.85 \mathrm{~m}$ and thickness of $0.16 \mathrm{~m}$. A total of 27 experiments were conducted to monitor the gasifier performance and the system can operate with the centrifugal blower operating at a power input of $155 \mathrm{~W}$ and a maximum flow rate of $1450 \mathrm{~m}^{3} / \mathrm{hr}$ regulated according to the air requirement. Building the UBRHG is simple and inexpensive to fabricate and with the fairly satisfactory performance and ease of construction along with the convenience of operation, the UBRHG with RH as feed would find abundant avenues of applications in a rural setting for biochar production alongside thermal, mechanical and electrical energy delivery.

\section{Keywords}

Biochar, Equivalence Ratio, Yield, Upscale Belonio, Rice Husk Gasifier

\section{Introduction}

With the increasing world population, there is a need to ensure food security to sustain the overwhelmingly in-

How to cite this paper: Nsamba, H.K., Hale, S.E., Cornelissen, G. and Bachmann, R.T. (2015) Designing and Performance Evaluation of Biochar Production in a Top-Lit Updraft Upscaled Gasifier. Journal of Sustainable Bioenergy Systems, 5, 41-55. http://dx.doi.org/10.4236/jsbs.2015.52004 
creasing population. This includes catering for land lost as part of poor farming practices as well as environmental degradation. In the past 40 years, 30 percent of the planet's arable land has become unproductive due to erosion [1]. Unless this trend is reversed soon, feeding the world's growing population will be impossible. A big part of reversing soil decline is through soil-carbon enrichment where soil can act as an environment where huge amounts of carbon from the atmosphere could be sequestered. Keeping and putting carbon in its rightful place need to be the mantra for humanity if we want to continue to eat, drink and combat global warming [1]. Leahy (2013) [1] revealed that healthy soils equal healthy crops, healthy livestock and healthy people where farmers and pastoralists (ranchers) can keep carbon in the soil and help to remove carbon from the atmosphere and feed the world if they are properly supported. On the other hand, if carbon present in biomass feed stocks is not properly managed, it can escape in the form of gases which subsequently contribute to global warming. Global warming is a threat to the world today [2]-[4] attributed by environmental factors such as the decomposition of biomass leading to large volume of greenhouse gas that escapes to the atmosphere and poor means of waste management such as open burning of agricultural wastes [5]-[7]. Biochar can be produced from traditional charcoal producing kilns; however these are unsuitable because they are highly inefficient and pollute the environment to a large extent. A more environmentally-friendly deigned kiln would solve this problem. Producing biochar from the wastes generated from agriculture produce can boost the agriculture sector if these wastes are efficiently and effectively converted into biochar and applied on soil. When biochar is used as a soil amendment tool, crop yields and productivity improve; soil acidity decreases; and the need for some chemical and fertilizer inputs decreases [8]. In addition, biochar amendment to soils provides a potential sink to the soil because of its ability to withstand chemical and biological degradation and being present in the soil for a long period of time. Biochar has the potential to improve low-fertility soils by enhancing the cation exchange capacity of the soil, increasing soil $\mathrm{pH}$ [9] as well as improving water holding capacity, thus resulting in increased crop yield. Its application to agricultural and forestry soils is a likely outlet due to its demonstrated productivity and soil health benefits [10]. This provides a solution for sustainable farming through improved agricultural practices. The Belonio Rice Husk Gasifier (BRHG) which particularly runs on RH is an innovative technology that can help in this environmental context because of its non-proprietary design and the feasible possibility for scaling up. Converting RH wastes to biochar solves waste disposal issues while mitigating climate change because the inherent carbon in biochar can be sequestered in soil for years. Johnson et al. (2009) [11] estimated that the carbon abatement cost from improved stove introduction is $\$ 5-8 / \mathrm{tCO}_{2}(60 \%$ adoption rate, including community and monitoring \& verification costs). Simon and Bumpus (2010) [12] revealed that there is indeed tremendous potential for both localized "intensive" benefits and also global "extensive" advantages emanating from scaled-up carbon-financed ICS (improved cook stove) programs. Such benefits can only be put to use through sustainable engineering designs. A lot of effort has been devoted during the past several decades to develop improved stoves with several types which reduce fuel use by $40 \%$ and equivalent reduction in associated emissions being produced at a rate greater than 100,000 units per year [13]. Using improved cooking stoves for biochar production is promising and the ability to upscale the devices is very useful, especially when it can be done without compromising biochar yield. The BRHG is a top lit updraft gasifier that passes primary air upwards through a longitudinal column filled with dry RH allowing pyrolysis and char gasification processes to consistently descend through the fuel bed when lit from the top. This design is simple to fabricate, portable, not proprietary and economically viable, and upscaling its design can produce biochar at significant yields which provided the strongest motivation for this work. Technologies striking a balance between user friendliness, energy efficiency, ease of adaptation and a reduction in emissions could be easily integrated into the local community for sustainable and environmentally-friendly biochar production suiting both the technical as well as the socio-economic aspects of biochar production. Good nonproprietary technologies can be customized to recover the produced heat as well as produce biochar to be added to soil in order to improve its agricultural properties. Based on the experimental results observed from an OBRHG, it is possible to produce biochar at a promising yield and customizing the design assists in achieving its purpose as a biochar production system. An UBRHG was thus designed and optimized for RH biochar production with an emphasis on determining the gasification time, electricity consumption, optimal char yield as well as the corresponding Equivalence Ratio (ER) and the costs of biochar production.

\section{Material and Methods}

\subsection{Rice Husk Collection}

RH samples were collected from Drpts Manufacturing Sdn Bhd Lot No. 6, Jalan Pbr 33, Phase 4C, Kawasan Pe- 
rindustrian Bukit Rambai, 75,250 Melaka, Malaysia for the study. RH samples were packed into polyethylene bags of approximately $10 \mathrm{~kg}$ per bag and transported to Malaysian Institute of Chemical and Bioengineering Technology (MICET), Universiti Kuala Lumpur (UniKL-MICET). The samples had a moisture content of 10\% when received and were stored in a cool dry place for future processing.

\subsection{Rice Husk Sample Preparation}

Air dried samples were ground to obtain a uniform material used for analysis [14]. The selected sample was ground slowly to avoid generation of heat that can cause loss of volatile matter (VM) and therefore lead to an inaccurate determination of moisture content (MC), VM, ash content (AC) and fixed carbon (FC). Too much grinding can result in the production of very fine particles that are vulnerable to escape with volatile gases during heating and should therefore be avoided.

\subsection{Design and Fabrication of the Upscale Gasifier}

The basis of sizing was based on the contemporary paddy yield for a conventional Malaysian farmer. The gasifier size was thus chosen by taking into account that an average small scale farmer can own a gasifier unit and use this to produce enough biochar from their rice husk for further use. A paddy yield of $3000 \mathrm{~kg} / \mathrm{ha} / \mathrm{harvest}$ where $10 \%$ or $300 \mathrm{~kg} / \mathrm{ha} /$ harvest is rice husk was assumed. A subsistence farmer owning 1 ha of land will produce $300 \mathrm{~kg}$ of RH per harvest and would need to convert this to biochar by assuming a fuel consumption rate (FCR) of $50 \mathrm{~kg} / \mathrm{hr}$ while operating at 2 hrs per shift with rice husk density, $\rho r h$ of $110 \mathrm{~kg} / \mathrm{m}^{3}$ and specific SGR of $90 \mathrm{~kg} / \mathrm{m}^{2} \cdot \mathrm{hr}$. The following design Equations (1) and (2) were used based on [15]-[17] and were used in order to obtain a size for the diameter $(D)$ and height $(H)$ of the Upscale Belonio Rice Husk gasifier

$$
\begin{gathered}
D=\sqrt{1.27 \mathrm{FCR} / \mathrm{SGR}} \\
H=\mathrm{SGR} \times t / \rho
\end{gathered}
$$

\subsection{Calculation of ER}

This is defined as the ratio of the actual fuel-to-oxidizer ratio to the stoichiometric fuel-to-oxidizer ratio [18], as shown in Equation (3)

$$
\mathrm{ER}=Q \times T / M \times(A / F)
$$

where:

$Q$, Rate of air supply, $\mathrm{m}^{3} / \mathrm{s}$

$T$, Duration of the run, hr

$M$, Mass input, $\mathrm{kg}$

$A / F$, Air to Fuel ratio at ER of $1, \mathrm{~m}^{3} / \mathrm{kg}$

The $A / F$ at $Q$ (ER of 1 ) is $4.5 \mathrm{~m}^{3} / \mathrm{kg}$ and the stoichiometric air of rice husk is $4.5 \mathrm{~kg}$ air per $\mathrm{kg}$ rice husk at air density of $1.25 \mathrm{~kg} / \mathrm{m}^{3}$ [15]. Zainal et al. (2002) [18] reported that ideal and theoretical gasification takes place in the ER range of $0.19-0.43$.

\subsection{Selection of the Fan}

While selecting the fan, it is safer to exercise caution and choose variables that are larger rather than smaller. This can assist in minimizing errors such as choosing fans with too low settings. Based on this, parameters were chosen as: density of RH between $70-110 \mathrm{~kg} / \mathrm{m}^{3}$, Specific gasification rate (SGR) of $90 \mathrm{~kg} / \mathrm{m}^{2} \mathrm{hr}$ from the OBRHG and thus the reactor can be filled with $100 \mathrm{~kg}$ gasified and the ER calculated. The A/F at Q (ER of 1 ) is $4.5 \mathrm{~m}^{3} / \mathrm{kg}$ and the stoichiometric air of rice husk, $4.5 \mathrm{~kg}$ air per $\mathrm{kg}$ rice husk at air density of $1.25 \mathrm{~kg} / \mathrm{m}^{3}$ and therefore, the superficial air velocity can be calculated according to equation 4 and the fan pressure drop computed from the Kaup graph [19].

$$
\text { Superficial Air Velocity-Vs }=4 \mathrm{AFR} / \pi D^{2}
$$

Thus a fan that has a pressure of nearly 291.06 pa at a controllable flow rate within that range is preferred. The UBRHG was designed for rice husk biochar production according to the technical drawing shown in Figure 
1 and was fabricated by Lowseong Engineering Sdn Bhd. The gasifier was designed and constructed using mild steel with $0.002 \mathrm{~m}$ thickness for the outer cylinder and biochar chamber while the inner cylinder was constructed from stainless steel of $0.001 \mathrm{~m}$ thickness. Both were constructed in a rectangular shape before initial metal welding into cylindrical shape. The insulation thickness between the inner and out cylinder was $0.16 \mathrm{~m}$ and was filled with thermal rock multipurpose slab S60-0.05 $\mathrm{m} \times 0.6 \mathrm{~m} \times 1.2 \mathrm{~m}$. The total height of the gasifier was 1.61 $\mathrm{m}$ with a diameter of $0.85 \mathrm{~m}$. The biochar chamber is the primary area for biochar removal and had dimensions of $1.25 \mathrm{~m}$ by $1.20 \mathrm{~m}$ by $0.25 \mathrm{~m}$ for length, width and height respectively. The rice husk feedstock was placed into the top of the reactor through the inlet and rests on the base. The base is designed in such a way that it is able to accommodate a grate which is manually inserted through the base to handle rice husk until the entire batch feeding process and gasification time is complete. The grate directly supports the combustion zone and must be capable of letting air through it and letting ash fall through it, without excessive loss of fuel. In addition, the grate is used to control reactor pressure drop. Air was supplied to the gasifier using an electric centrifugal blower (R2E250AS4705) with a control valve capable of supplying the necessary air at constant velocity.

\subsection{A Step by Step Biochar Production in the UBRHG}

Biochar in UBRHG was produced sequentially according to the following steps below and is shown as a technical diagram in Figure 2 and pictorial set up in Figure 3.

1) Weigh $90 \mathrm{~kg}$ of dried rice husks.

2) Transfer the pre-weighed $90 \mathrm{~kg}$ of rice husks into the reactor at intervals, while ensuring that all the mass is properly fed into the reactor without any loss to the ground.

3) Close biochar chamber and seal any air holes to ensure no air leakage from the centrifugal fan (R2E250AS4705). The centrifugal fan can operate up to $1450 \mathrm{~m}^{3} / \mathrm{hr}$ maximum air supply at a power input of $155 \mathrm{~W}$.

4) Run the centrifugal fan at maximum power and measure the air velocity at the inlet with the anemometer (BENETECH, GM8908) while controlling the fan speed using a fan controller of 230V, 5A (ebm papst, REE30) equipped with a $5 \mu \mathrm{F}$ Capacitor.

5) Connect the fan to the electrical power supply and monitor electricity consumption.

6) Add $10 \mathrm{~g}$ of paper to the top of the rice husk and ignite using a lighter.

7) After 1 - 2 min the combustion process is initiated and the counting time started for both the time required to complete the gasification for each cycle, the velocity of incoming air as well as the energy used by the fan.

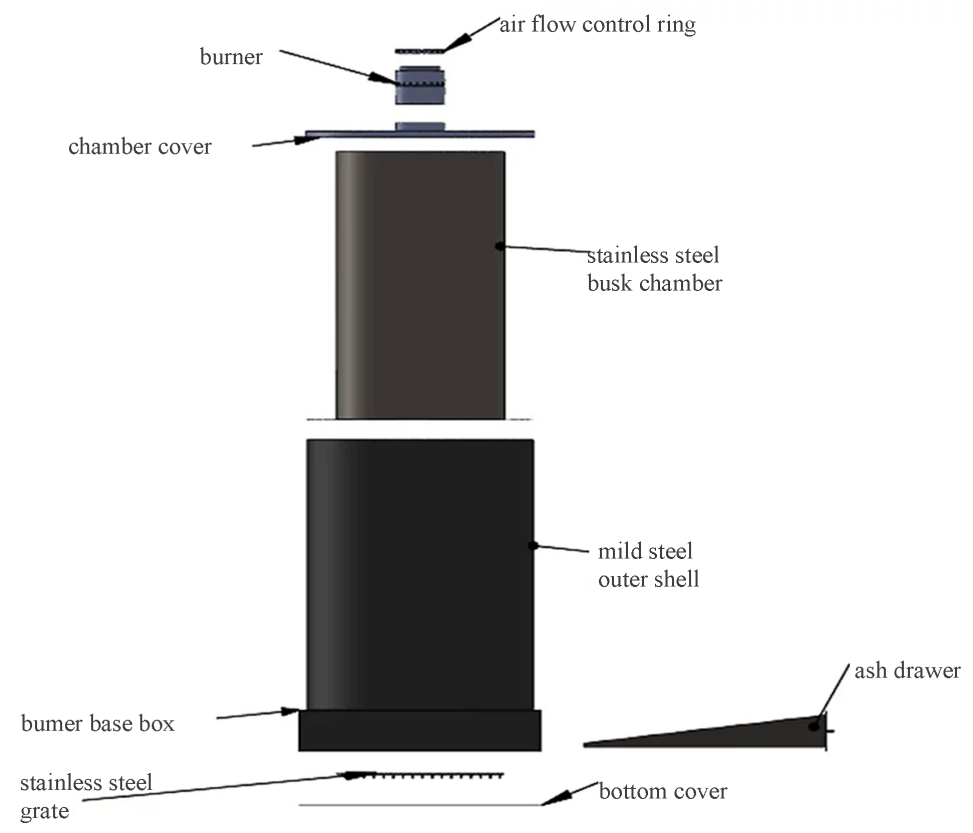

Figure 1. Technical assembly of the upscale Belonio. 


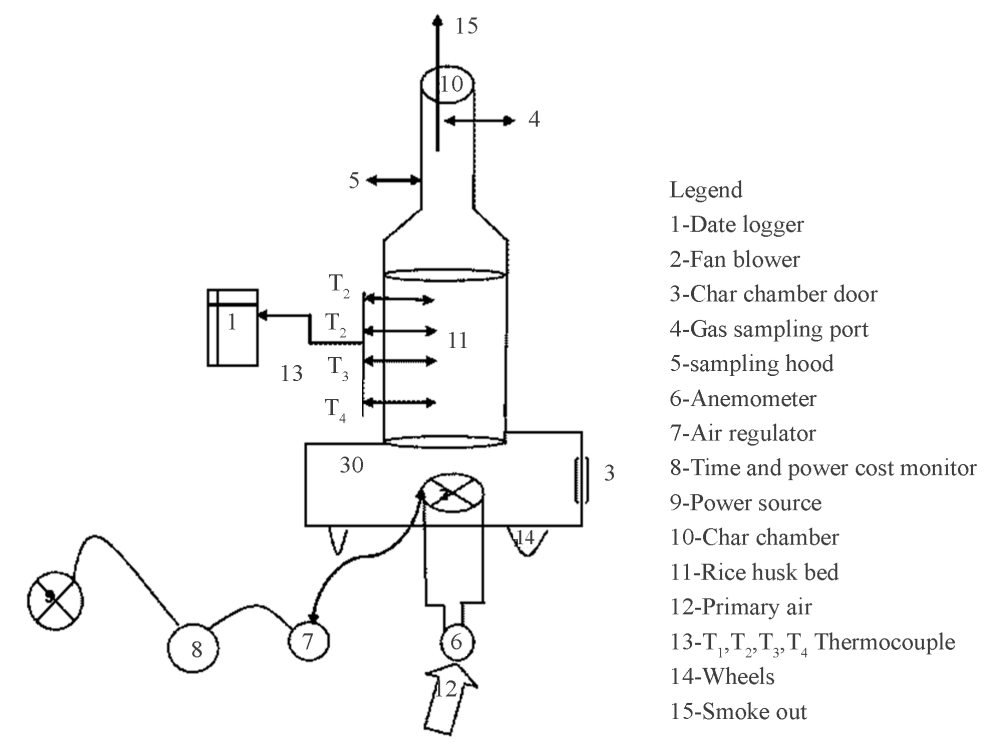

Figure 2. Schematic diagram of the experimental biochar production in the original Belonio Rice Husk Gasifier.

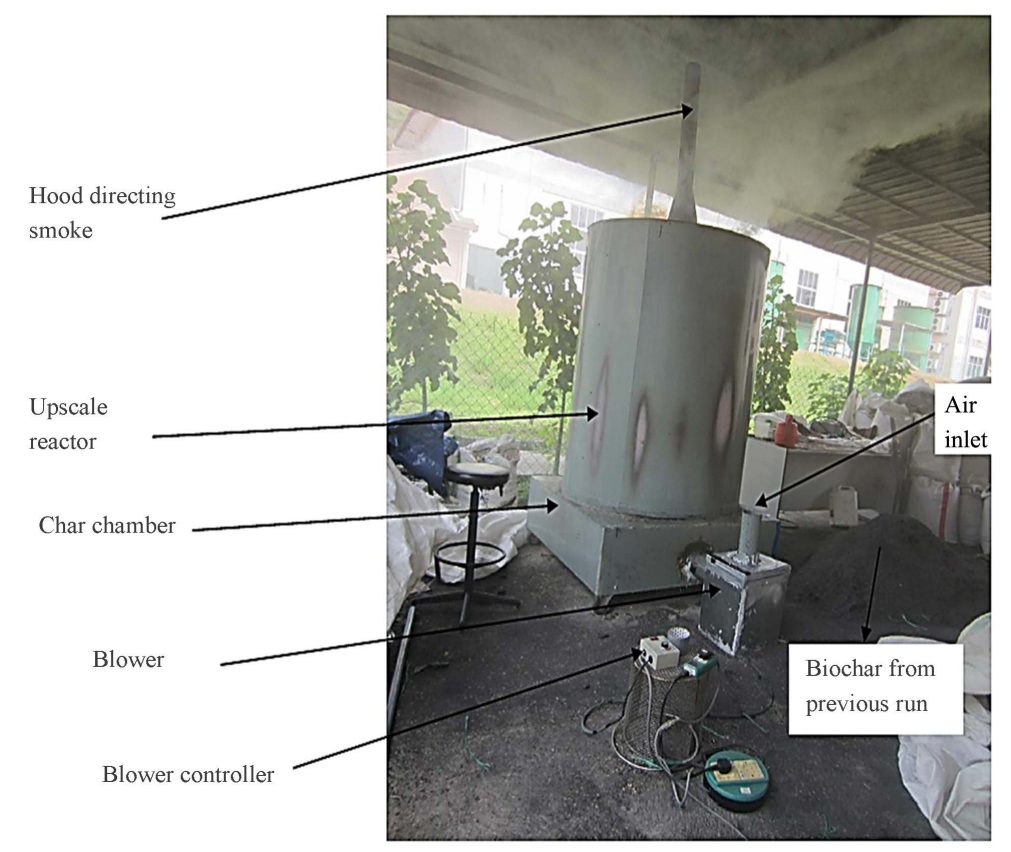

Figure 3. The pictorial of experimental set up of the upscale Belonio.

8) The end of the gasification process is confirmed by the change of the smokeless mode. At the end of gasification, the grate region is very hot confirming that the combustion zone has reached the bottom end of the gasifier reactor. At this point, the power consumption and the time taken to complete the gasification process noted.

9) The fan is stopped once this is confirmed, top burner removed and about 20litres of water sprinkled from the top of the reactor into the biochar to cool it down.

10)The biochar chamber is opened carefully and biochar removed with the help of a hoe.

11)The colder biochar is carefully weighed and other conventional cycles follow the same routine.

12)Moisture content is conducted to determine the actual yield of biochar for a given run. 
The temperatures along the gasifier height are also monitored by the already configured thermocouple systems in the reactor.

\subsection{Temperature and Velocity Monitoring along the Reactor}

The temperature along the reactor height was monitored by using a data logger (TM-747DU, TENMARS). The data logger was fitted with a K-type thermocouple (TME, 01903-700651) one meter long and supplied by RS Malaysia Sdn Bhd. A total of 12 holes were drilled along the reactor where the first three were equidistantly positioned at a height of $0.20 \mathrm{~m}$ from the top, the next three were $0.585 \mathrm{~m}$, the next three at $0.965 \mathrm{~m}$ and the last three placed at $1.345 \mathrm{~m}$ from the top. Thermocouples were placed equidistantly at the same positioning angle along the reactor height so that a representative temperature could be reported at the same height. The thermocouple heat sensing end point was positioned into the reactor inner wall and came into direct contact with the biomass $\mathrm{RH}$, while the other end was fixed into the data logger and the temperatures recorded as soon as the reading was stable. Incoming air velocity and temperature was monitored with anemometer (BENETECH, GM8908) from the start of the experiment until the end. The total volumetric flow rate was computed as a product of incoming air velocity and the cross sectional area for the anemometer air inlet.

\subsection{Shutdown Procedure}

Once the total gasification time has been confirmed with no smoke exiting from the top of the reactor and the combustion zone has travelled till the grate, the electricity power supply is turned off. This prevents unnecessary air supply that would otherwise combust the biochar to ash. The lid is uncovered from the top, carefully removed and allowed to cool before the next run begins. When $100 \mathrm{kgs}$ of RH are used for biochar production in the upscale reactor, between 20 - 25 litres of water are sprinkled inside the hot reactor for char cooling before the char is removed for storage and later transported to the farm for soil application. Removal of the biochar involves drawing the char chamber carefully where the cooled char is carefully drawn from the chamber box using a hoe. Char is cooled at this condition and subsequent runs continue. It takes about 10 - 15 min for the reactor to cool down which allows subsequent runs to be executed or left overnight until the next run.

\subsection{Proximate Analysis}

The rice husk was characterized for proximate analysis using a muffle Furnace (carbolite ELF 11/14B; max $1100^{\circ} \mathrm{C}$ ) where subsequent gravimetric measurements were done using analytical balance (Mettler Toledo; B204-S; 0 - 220 g). The proximate analysis was performed on fine-ground oven-dried samples to determine the weight fractions of volatiles, ash, and fixed carbon in the rice husk. The ASTM standard method for proximate analysis of wood [20] was used, while fixed carbon content calculated by subtracting from 100 the sum of volatile matter and ash contents [21]. MC of oven-dried ground specimen is calculated as a proportion of its initial weight.

$$
\text { MC, } \%=\frac{A-B}{A} \times 100
$$

where $A=$ grams of air dry sample, $B=$ grams of sample after drying at $105^{\circ} \mathrm{C}$.

The same specimen is used for VM and AC determination. VM is extracted by pre-heating the specimen in a muffle furnace (as an alternative to the tube furnace) for two minutes at $300^{\circ} \mathrm{C}$ then heating for three minutes at $500^{\circ} \mathrm{C}$ and for six minutes at $950^{\circ} \mathrm{C}$. Volatile matter content (Equation (6)) is calculated as a proportion of the oven-dry weight of the charcoal specimen.

$$
\mathrm{VM}, \%=\frac{B-C}{B} \times 100
$$

where $C=$ grams of sample after drying from $950^{\circ} \mathrm{C}$.

AC is determined by heating the rice husk specimen in an uncovered crucible at $750^{\circ} \mathrm{C}$ for six hours. The ash samples were allowed to cool down in a desiccator and then weighed. Ash content is calculated as a proportion of the oven-dry weight of the oven-dry weight of the residue to the oven-dry weight of specimen.

$$
\text { Ash, } A \%=\frac{D}{B} \times 100
$$


where $D$ = grams of residue.

The carbon content is usually estimated as a "difference", that is to say, all the other constituents are deducted from 100 as percentages and the remainder is assumed to be the per cent of "pure" or "fixed" carbon. Results are reported on as received as well as on a dry basis.

\subsection{Ultimate Analysis}

The ultimate analysis was achieved by following Dumas combustion technique (Dumas, 1826 as cited by [22]) using an elemental analyzer LECO CHN628 Series. The instrument utilizes a combustion technique and provides a result within $4.5 \mathrm{~min}$. The machine also offers a sulphur add-on module which provides sulphur analysis. For the CHN analysis, $350 \mathrm{mg}$ of dried and crushed samples were weighed and mixed in a tin capsule, then combusted in a primary furnace at $950^{\circ} \mathrm{C}$ and secondary furnace at $850^{\circ} \mathrm{C}$ in the presence of pure oxygen. The oxidized products $\mathrm{CO}_{2}, \mathrm{H}_{2} \mathrm{O}$ and $\mathrm{NO}_{2}$ passed through a series of drier to remove moisture, and homogenized before being carried by a constant flow of carrier gas (helium), and finally $\mathrm{CO}_{2}$ and $\mathrm{H}_{2} \mathrm{O}$ separated and quantified with a non-dispersive infrared (NDIR) cell, while the $\mathrm{NO}_{2}$ gases were passed through a copper reducer, the gas was reduced to $\mathrm{N}_{2}$, and quantified with a thermal conductivity cell (TCD). The chromatographic responses are calibrated against pre analyzed standards, and the CHN elemental contents are reported in weight percent.

For S, the sample was weighed into a combustion boat and placed in the furnace with pure oxygen at $1350^{\circ} \mathrm{C}$. The oxidized gases in the combustion system flow through an anhydrone tube to remove moisture, and quantified in the sulphur infrared detection cell. The final results for sulphur is displayed in weight \% or parts per million (ppm). Total O was derived by subtraction according to the ASTM method [23] as follows

$$
\mathrm{O}\left(\% \frac{w}{w}\right)=100-\operatorname{ash}\left(\% \frac{w}{w}\right)-\mathrm{C}\left(\% \frac{w}{w}\right)-\mathrm{N}\left(\% \frac{w}{w}\right)-\mathrm{H}\left(\% \frac{w}{w}\right)
$$

\section{Results and Discussion}

\subsection{Ultimate and Proximate Analysis of Biochar from Upscale Belonio}

Results for ultimate and proximate analysis are summarized in Table 1 and Table 2 respectively. Based on proximate results in Table 2, biochar produced from the Upscale Belonio has a higher FC of $51.5 \% \pm 0.64 \%$

Table 1. Ultimate analysis (moisture and ash free) of biochar from Belonio gasifier.

\begin{tabular}{cc}
\hline Element & $\begin{array}{c}\text { Ultimate values } \\
\text { at ER }(0.1118 \pm 0.02)\end{array}$ \\
$\mathrm{C}$ & $45.8 \pm 4.5$ \\
$\mathrm{H}$ & $0.870 \pm 0.233$ \\
$\mathrm{~N}$ & $1.08 \pm 0.42$ \\
$\mathrm{~S}$ & $0.0685 \pm 0.0203$ \\
$\mathrm{O}$ & 15.6 \\
$\mathrm{H} / \mathrm{C}$ & 0.228 \\
$\mathrm{O} / \mathrm{C}$ & 0.255 \\
\hline
\end{tabular}

Table 2. Proximate analysis of rice husk and rice husk char.

\begin{tabular}{|c|c|c|c|}
\hline & $\begin{array}{l}\text { Upscale Belonio char on dry basis at } \\
\qquad \mathrm{ER}=0.3366\end{array}$ & $\begin{array}{l}\text { Small Belonio char on dry basis at } \\
\qquad \mathrm{ER}=0.2916\end{array}$ & $\begin{array}{l}\text { Original rice husk } \\
\text { on dry basis }\end{array}$ \\
\hline Moisture Content, MC \% & $47.1 \pm 0.85$ & & \\
\hline Volatile Matter, VM \% & $11.0 \pm 0.5$ & $14.1 \pm 0.18$ & $83.9 \pm 1.21$ \\
\hline Ash Content, AC \% & $37.5 \pm 1.0$ & $33.7 \pm 0.39$ & $10.0 \pm 1.23$ \\
\hline Fixed Carbon, FC \% & $51.5 \pm 0.64$ & $50.5 \pm 0.69$ & $6.1 \pm 0.22$ \\
\hline
\end{tabular}


which makes it good and suitable for soil applications, the higher the fixed carbon, the longer its recalcitration value. Biochar is highly recalcitrant in soils, with reported residence times for wood biochar being in the range of 100s to 1000s of years, i.e. approximately 10 - 1000 times longer than residence times of most soil organic matter [24]. There is a very close relationship between the properties of the char produced by both reactors as revealed from their proximate composition. They nearly have properties in the same magnitude. This justifies the prospect of scaling up the design for large scale biochar production. The slightly higher ash content in the upscale Belonio char is due to the higher ER during operation. A higher ER has a bearing with the amount of oxygen responsible for carbon oxidation and subsequently ash formation. Raw rice husk has a low fixed carbon with low resistance to degradation when applied to soil. The results for rice husk char elemental analysis as shown in Table 1 for carbon, hydrogen, nitrogen and sulphur revealed a composition of $45.8 \% \pm 4.46 \%, 0.87 \% \pm$ $0.233 \%, 1.08 \% \pm 0.418 \%$ and $0.0685 \% \pm 0.0203 \%$ respectively. The elemental carbon content as a major factor determining the quality of biochar compares well with other biochar produced from different technologies such as gasified forestry from downdraft moving bed gasifiers with carbon content of $45.8 \%$ [25] as well as $39.7 \%$ for biochar production by sewage sludge pyrolysis in a muffle furnace at $300^{\circ} \mathrm{C}$ with a residence time of 30 minutes [26]. The IBI recommends only a maximum value of 0.7 for the molar $\mathrm{H} / \mathrm{C}$ ratio [27] which distinguishes biochars from biomass that has not been thermochemically altered and from other materials that have been only somewhat thermochemically altered. Biochar produced from the Belonio gasifier conforms to this requirement.

\subsection{Variation of Air Inlet Cross Sectional Area with Char Yield}

A variation of air inlet cross sectional area was tested against char yield with detailed results reported in Table 3 and the pictorial of experimental set up of the upscale Belonio shown in Figure 3. In the 27 experiments conducted in Table 3, air was supplied at varied cross sections. Air was directly sucked with no hood to the fan housing through a diameter of $0.16 \mathrm{~m}$, with a hood of $0.1 \mathrm{~m}$ on top of the fan housing and also though a very small air inlet via the anemometer holes of cross section $0.00035384 \mathrm{~m}^{2}$ while the fan setting is not adjusted. The yield for runs 1 - 16 considerably varies due to the different incoming velocity at varied cross section area. The higher the air volumetric flow rate, the lower the char yield. This is probably due to faster kinetic reactions taking place inside the reactor where the rate of carbon oxidation is faster than the rate of char formation and subsequently a lower char yield. The difference in char yield and gasification time (Table 3) at varying cross section may be explained as below

1) When the air entering the blower is open without any enclosure to direct the flow of air, some of the air is directed back to the outside due to the rotating fan blades and the total air going to the reactor may not be $100 \%$ as sucked from the ambient. This is revealed due to the difference in gasification times for experiments conducted at similar fan settings (such as run 3 or 4 and 11 or 14). Complete rice husk gasification is achieved earlier when a chimney is inserted on top which reveals that more air enters and the total air required for gasification is achieved faster.

2) By inserting a chimney on top of the blower housing to direct the flow of incoming air, the overall airflow rate is probably faster than when the blower is not housed since the housing acts by directing the flow of air to the reactor.

3) Without putting housing at the fan blower, measuring the actual velocity of air may not be representative. A blower housing such as a hood ensures allows uniform air flows which make measurement of velocity easier and subsequently the calculation of ER simplified.

4) Run 6 and 7 have a variably longer gasification time from the previous runs. This is because the particle size of the gasified rice husk was varied. Fined rice husk was gasified for experiments 5, 6 and 7 while original rice husk was gasified for other experiments. Fine rice husk is denser and creates a high resistance to air flow inside the reactor making the flow of incoming gasifying air very slow. This subsequently affects the kinetic reactions as revealed from longer residence gasification times.

5) By varying the fan settings (Table 3) from maximum (runs 3, 4) to lowest fan setting (run 9,10 and 12) via similar cross section through a diameter of $0.16 \mathrm{~m}$ for incoming air, the biochar yield increases from $18.94 \%$ to $24.96 \%$ respectively. This reveals that more air oxidizes the char to ash.

6) Supplying more air from the inlet speeds up the reactions, producing gasification products at a faster rate with formation of syngas at the reactor top. 
Table 3. Variation of major parameters for experiments conducted in the Upscale Belonio Rice Husk Gasifier (UBRHG).

\begin{tabular}{|c|c|c|c|c|c|c|c|c|c|}
\hline Run & $\begin{array}{l}\text { RH } \\
\text { type }\end{array}$ & $\begin{array}{c}\text { Mass } \\
\text { input/kg }\end{array}$ & $\begin{array}{l}\text { Fan } \\
\text { mode }\end{array}$ & $\begin{array}{c}\text { Air } \\
\text { inlet diameter/cm }\end{array}$ & $\begin{array}{l}\text { Wet Char } \\
\text { out/ kg }\end{array}$ & $\begin{array}{l}\text { Char } \\
\text { MC \% }\end{array}$ & $\begin{array}{l}\text { Char yield } \\
\text { (\%Dry basis) }\end{array}$ & $\begin{array}{c}\text { Energy } \\
\text { consumption } \\
\text { (kWh) }\end{array}$ & $\begin{array}{c}\text { Gasification } \\
\text { time/min }\end{array}$ \\
\hline 1 & $\mathrm{BRH}$ & 90 & Maximum & 2 & 56.2 & 47.10 & 33.03 & 0.6 & 330 \\
\hline 2 & BRH & 93 & Maximum & 16 & 33.5 & 25.94 & 27.08 & 0.2 & 130 \\
\hline 3 & $\mathrm{BRH}$ & 89.5 & Maximum & 16 & 32.5 & 41.73 & 18.94 & 0.2 & 120 \\
\hline 4 & $\mathrm{BRH}$ & 91.4 & Maximum & 16 & 33.1 & 45.09 & 19.88 & 0.2 & 120 \\
\hline 5 & $\mathrm{BRH}$ & 83.4 & Maximum & 16 & 38.5 & 40.20 & 25.6 & 0.3 & 157 \\
\hline 6 & $\mathrm{BRH}$ & 96.3 & Maximum & 16 & 35.5 & 43.20 & 20.9 & 0.5 & 249 \\
\hline 7 & $\mathrm{BRH}$ & 86.5 & Maximum & 16 & 32.7 & 42.70 & 21.7 & 0.8 & 420 \\
\hline 8 & ORH & 90.9 & Maximum & 16 & 27.3 & 37.32 & 18.82 & 0.2 & 125 \\
\hline 9 & ORH & 90 & Lowest & 16 & 33.9 & 35.20 & 24.4 & 0.3 & 150 \\
\hline 10 & ORH & 90 & Lowest & 16 & 29.1 & 36.28 & 20.6 & 0.3 & 150 \\
\hline 11 & ORH & 90 & Maximum & 10 & 31 & 36.20 & 21.97 & 0.2 & 112 \\
\hline 12 & $\mathrm{ORH}$ & 88.9 & Medium & 16 & 33.5 & 33.80 & 24.96 & 0.3 & 150 \\
\hline 13 & $\mathrm{ORH}$ & 90 & Medium & 10 & 35.1 & 37.60 & 24.3 & 0.4 & 164 \\
\hline 14 & ORH & 90 & Maximum & 10 & 28.6 & 38.15 & 19.65 & 0.2 & 105 \\
\hline 15 & ORH & 90 & Lowest & 10 & 39.4 & 36.70 & 27.7 & 0.4 & 186 \\
\hline 16 & ORH & 90 & Maximum & 10 & 23.4 & 13.50 & 22.5 & 0.2 & 116 \\
\hline 17 & ORH & 90 & Lowest & 10 & 36.2 & 34.70 & 26.3 & 0.4 & 170 \\
\hline 18 & UBRH & 90 & Lowest & 10 & 38.4 & 35.40 & 27.6 & 0.4 & 166 \\
\hline 19 & ORH & 90 & Lowest & 10 & 43 & 33.00 & 32.01 & 0.7 & 270 \\
\hline 20 & ORH & 90 & Lowest & 10 & 38.8 & 33.92 & 28.5 & 0.4 & 165 \\
\hline 21 & ORH & 90 & Lowest & 10 & 32.4 & 28.50 & 25.82 & 0.3 & 130 \\
\hline 22 & ORH & 89.8 & Lowest & 10 & 37 & 34.45 & 27.01 & 0.4 & 168 \\
\hline 23 & ORH & 89.6 & Lowest & 10 & 38.9 & 30.20 & 30.3 & 0.4 & 169 \\
\hline 24 & ORH & 91.3 & Lowest & 10 & 34.9 & 30.20 & 26.68 & 0.5 & 192 \\
\hline 25 & ORH & 90.4 & Lowest & 10 & 38.6 & 41.30 & 26.21 & 0.5 & 180 \\
\hline 26 & ORH & 92 & Lowest & 10 & 40.1 & 36.90 & 27.5 & 0.4 & 160 \\
\hline 27 & ORH & 91.3 & Lowest & 10 & 38.7 & 37.30 & 26.58 & 0.4 & 170 \\
\hline \multicolumn{10}{|l|}{$\mathrm{n}=27$} \\
\hline $\mathrm{Av}$ & & & & & & & 25.06 & 0.37 & 175.0 \\
\hline SD & & & & & & & 3.8488 & 0.156 & 69.83 \\
\hline
\end{tabular}

7) The above observations give a realistic view for ER measurements while using fan housing with a hood whose diameter is $0.10 \mathrm{~m}$ where ER was reproducibly computed.

Generally, the reactor performance for a yield between $26 \%$ - 33\% compares well with the performance of slow pyrolysis reactors as revealed by [28] with a yield of 30\% for biochar from retorts; as well as [29] with a yield of $22.9 \%-28.2 \%$ for biochar from a conventional pilot pyrolysis plant at $400^{\circ} \mathrm{C}$; [14] for biochar from biomass pyrolysis in an inert atmosphere at $550^{\circ} \mathrm{C}$ with a yield between $25.2 \%-29.7 \%$ and [30] with a yield of 
$27 \%-29 \%$ for fixed bed pyrolysis of rice husk between $550^{\circ} \mathrm{C}$ and $600^{\circ} \mathrm{C}$. The competitive advantage with the UBRHG is its ability to process up to $90 \mathrm{kgs}$ of rice husk in just $2.5 \mathrm{hrs}$.

\subsection{Effect of ER with Gasification Time}

As shown in Table 3 above, the gasification time of 330min is longer. This is because the air inlet is considerably small. It takes 330 min to suck the total amount of air required to gasify $90 \mathrm{kgs}$ of rice husk to produce this biochar at ER of 0.3366 . The same amount of air can be sucked in a less time by increasing the size of the cross section for the air inlet which accounts for the different gasification times between 105 - 270 min in Table 3, the wider the cross section for air inlet, the faster the air velocity. This has a bearing to the reaction kinetics inside the gasifier. The ER at this fan setting however reveals the proportionate amount of air required for a substantial yield of 33\%. The initial incoming air velocity did not change till the end of the experiment. This may be due to a stronger fan pressure resistance not to be affected by the smaller changes due to the change in the density of rice husk during char formation.

\subsection{ER and Temperature Profile along the Gasification Height}

For ER variation against the movement of the combustion zone, the variation is shown in Table 4 and Table 5

Table 4. Variation of ER with the speed of combustion zone for UBRHG.

\begin{tabular}{|c|c|c|c|c|}
\hline Run & ER & $\begin{array}{l}\text { Gasification } \\
\text { Time/min }\end{array}$ & $\begin{array}{c}\text { Speed of combustion zone along } 161 \mathrm{~cm} \text { gasification } \\
\text { height }\end{array}$ & $\%$ Dry char yield \\
\hline Run 17 & 0.5100 & 170 & 0.95 & 26.3 \\
\hline Run 18 & 0.5308 & 166 & 0.97 & 27.6 \\
\hline Run 23 & 0.5027 & 169 & 0.95 & 30.3 \\
\hline Run 26 & 0.4864 & 160 & 1.01 & 27.5 \\
\hline Run 27 & 0.5162 & 170 & 0.95 & 26.58 \\
\hline \multicolumn{5}{|l|}{$\mathrm{n}=5$} \\
\hline $\mathrm{Av}$ & 0.5092 & 167 & 0.97 & 27.67 \\
\hline SD & 0.0164 & 4.2 & 0.026 & 1.58 \\
\hline Run 19 & 0.3957 & 260 & 0.62 & 32.01 \\
\hline Run 21 & 0.3993 & 130 & 1.23 & 25.82 \\
\hline \multicolumn{5}{|l|}{$\mathrm{n}=2$} \\
\hline $\mathrm{AV}$ & 0.3975 & 195 & 0.925 & 28.90 \\
\hline SD & 0.0026 & 91.9 & 0.43 & 4.40 \\
\hline Run 20 & 0.4466 & 165 & 0.98 & 28.05 \\
\hline Run 22 & 0.4618 & 168 & 0.96 & 27.01 \\
\hline \multicolumn{5}{|l|}{$\mathrm{n}=2$} \\
\hline $\mathrm{AV}$ & 0.4542 & 166.5 & 0.97 & 27.53 \\
\hline SD & 0.0108 & 2.1 & 0.014 & 0.74 \\
\hline Run 24 & 0.5672 & 192 & 0.84 & 26.68 \\
\hline Run 25 & 0.5652 & 180 & 0.89 & 26.21 \\
\hline \multicolumn{5}{|l|}{$\mathrm{n}=2$} \\
\hline $\mathrm{AV}$ & 0.5662 & 186 & 0.865 & 26.445 \\
\hline SD & 0.0014 & 8.485 & 0.035 & 0.33 \\
\hline
\end{tabular}


Table 5. Variation of ER with the speed of combustion zone for OBRHG.

\begin{tabular}{cccccc}
\hline Time/min & ER & $\begin{array}{c}\text { Yield } \\
\text { \% }\end{array}$ & Speed cm/min & RH type & Reactor type \\
\hline $\mathbf{6 9}$ & 0.0998 & 31.3 & 0.86 & ORH & OBRHG \\
$\mathbf{6 9}$ & 0.1002 & 30.7 & 0.86 & ORH & OBRHG \\
$\mathbf{6 9}$ & 0.1353 & 29.5 & 0.86 & ORH & OBRHG \\
Av 69 & 0.1118 & 30.5 & 0.86 & & OBRHG \\
SD 0 & 0.020 & 0.92 & 0.0 & FRH & OBRHG \\
$\mathbf{1 2 0}$ & 0.2911 & 26.31 & 0.49 & FRH & OBRHG \\
$\mathbf{1 2 0}$ & 0.2867 & 26.07 & 0.49 & FRH & \\
A11 117 & 0.297 & 25.27 & 0.53 & 0.50 & \\
\hline
\end{tabular}

revealing the range for biochar production when air is allowed to pass through a $0.10 \mathrm{~m}$ diameter hood with internal diameter of $0.097 \mathrm{~m}$. Further ER calculations at the nearly similar setting are revealed between experiments 17 - 27. From Table 4 and Table 5, the higher the ER, the faster the combustion zone. This is because less time is required to complete the kinetic reactions inside the reactor. A lower ER is associated with a higher yield and running the reactor at a longer residence time maximizes char yield but takes longer to complete the gasification of RH due to slower rates of reactions.

Temperatures results (Table 6) revealed that combustion starts from the top and from the core of the reactor and distributes towards the reactor walls. This is because the blower is positioned at the centre of the reactor which accounts for even heat distribution. Also, the initial flaring of the reactor during start up is initiated from the Centre. This may account for even temperature distribution. The even temperature distribution per height was confirmed by the relatively minimal temperature variations reported by thermocouples placed along the same height. The biochar from OBRHG with a yield of nearly $30 \%$ is formed between $450^{\circ} \mathrm{C}-700^{\circ} \mathrm{C}$. This shows that the temperature build up descends from top to bottom where $\mathrm{T} 4>\mathrm{T} 3>\mathrm{T} 2>\mathrm{T} 1$. This is because as the zone descends downwards, the amount of RH that converts to biochar and thermal energy generation as part of the gasification products increases. These temperatures increase due to cumulative heat as the reactions near completion.

\subsection{Comparison of Rice Husk Gasification in Small and Upscale Belonio}

Original rice husk (ORH) as RH in its original form and size was subsequently gasified in the OBRHG with results published in a separate article [31]. The reproducibility of yield between $26-31 \%$ is possible for ORH, as well as fine rice husk (FRH) or partially crushed RH in UBRHG and OBRHG. There is however a great variation of ER for both reactors and rice husk type. To achieve a nearly similar yield of $30.5 \% \pm 0.92 \%$ in the OBRHG with original RH, there is an increase in ER from $0.1118 \pm 0.020$ to $0.2916 \pm 0.005$, about $160 \%$ increase in air supply with fined RH in OBRHG and an increase in ER up to $0.4704 \% \pm 0.029 \%$, about $320 \%$ with ORH in UBRHG. Gasifying RH in the two reactors of the same design but of different size with the bigger one having a volume scale factor of 93.8 increases the ER by $320 \%$ to attain a nearly similar yield of $30 \%$. To achieve this yield, the movement of the combustion zone is slower (about $0.50 \pm 0.02$ ) with fined RH and higher (about 0.86) ORH in the OBRHG while it is $0.96 \pm 00.015$ for UBRHG, The slow movement of the combustion zone with the FRH is due to the resistance of air flow due to more dense RH particles. Subsequently, the SGR increased from $47.4 \mathrm{~kg} / \mathrm{m}^{2} \cdot \mathrm{hr}$ to $56.9 \mathrm{~kg} / \mathrm{m}^{2} \cdot \mathrm{hr}$, an increase in SGR of about $20 \%$ for small and upscale RH gasifier respectively while producing a char yield of the same magnitude (about 30\%). In the same way Table 6 reveal the maximum available temperatures as the combustion zone travels down the grate. For a yield of about $30 \%$ from both reactors, the temperatures recorded in UBRHG are higher than the one's reported in the OBRHG. 
Table 6. Temperature profile along the gasification height of OBRHG with ORH.

\begin{tabular}{|c|c|c|c|}
\hline Run 28 & Temp $/{ }^{\circ} \mathrm{C}$ & Time/min & Height from Top/cm \\
\hline T1 & 196 & 30 & 5 \\
\hline $\mathbf{T} 2$ & 358 & 36 & 18.5 \\
\hline T3 & 561 & 40 & 32 \\
\hline T4 & 683 & 65 & 35.5 \\
\hline \multicolumn{4}{|l|}{ Run 29} \\
\hline Temp $/{ }^{\circ} \mathrm{C}$ & & & 5 \\
\hline T1 & 312 & 20 & 18.5 \\
\hline T2 & 463 & 30 & 18.5 \\
\hline T3 & 485 & 40 & 32 \\
\hline T4 & 615 & 65 & 35.5 \\
\hline \multicolumn{4}{|l|}{ Run 30} \\
\hline \multicolumn{4}{|l|}{$\operatorname{Temp} /{ }^{\circ} \mathrm{C}$} \\
\hline T1 & 368 & 25 & 5 \\
\hline T2 & 395 & 38 & 18.5 \\
\hline T3 & 443 & 60 & 32 \\
\hline $\mathbf{T 4}$ & 577 & 65 & 35.5 \\
\hline
\end{tabular}

This is because the UBRHG fills up more RH, about 10times more than the OBRHG. The more gasified RH, the more thermal energy generated and subsequently the higher the temperatures. Biochar produced in the OBRHG at a yield of $30 \%$ produced temperatures between $350^{\circ} \mathrm{C}-615^{\circ} \mathrm{C}$ from top to bottom while the temperature produced in the UBRHG ranged between $388^{\circ} \mathrm{C}-1045^{\circ} \mathrm{C}$ from top to bottom. The temperature gradient increases from top to bottom in both reactors as the combustion zone moves down the grate because more $\mathrm{RH}$ is converted into char with generation of cumulative thermal energy along the reactor walls as the zone descends down wards.

\subsection{Economic Feasibility of Investment in the UBRHG for Char Production}

Details on economic aspects are summarized in Table 7. The prospect for using the UBRHG as a biochar system is more economical when rice husk is free from farmers which costs $\$ 207.9 /$ ton compared to $\$ 333.3$ 368.2/ton when RH is not free. By costing the amount of carbon offset by the UBRHG, it would further reduce on the cost of biochar production. Producing biochar on a feedstock free basis is supported by [32] whose findings revealed that it may be profitable to apply biochar as a soil amendment if the biochar market price is low enough, lower than $\$ 12.14$ and $\$ 100.73 / \mathrm{MT}$ when the price of carbon offset is $\$ 1$ and $\$ 31 / \mathrm{MT} \mathrm{CO}_{2}$, respectively. The cost of biochar production by Galinato et al. (2011) [32] is lower than the current study because of their costing the amount of carbon offset by the biochar system which reduces the overall biochar production costs. Subsequently, the ROR on investment on a rice husk free basis is higher, about $72.4 \%-90.4 \%$ compared to $0.044 \%-10.5 \%$ when RH is not for free. A similar observation was made by [33] and [34] when they concluded that the economic viability of the pyrolysis-biochar system is largely dependent on the costs of feedstock production, pyrolysis, and the value of carbon offset.

\section{Conclusion}

The gasifier can be implemented to process rice husk char applied to soil. Original rice husk of $90 \mathrm{~kg}$ was gasified in nearly 2.5 hrs at a yield of $26 \%-27 \%$ in two batches per day. This operates with the centrifugal blower 
Table 7. Economic evaluation of biochar production in the upscale reactor (1 USD = 3.53700 MYR).

\begin{tabular}{|c|c|}
\hline Item & Costs \\
\hline $\begin{array}{c}\text { 1. Unit cost } \\
\text { (material cost, fabrication and labor) }\end{array}$ & RM 3000 or RM 300 annuitized for 10 years \\
\hline 2. Centrifugal blower & RM 1130 or RM 113 annuitized for 10 years \\
\hline 3. Labor and operation costs & RM 10,800/yr/labor \\
\hline 4. Fan controller & RM 405 or RM 40.5 annuitized for 10 years \\
\hline 5. Annual depreciation & RM 458 \\
\hline 6. Miscellaneous and maintenance & RM 300 \\
\hline 7. Annual price of raw RH and transportation & $\begin{array}{l}66.434 \text { tones = RM } 8769.3 \text { - } 10961.6 \text { (cost of RH/year) } \\
\text { (But can also be considered free from farmers) }\end{array}$ \\
\hline 8. Annual electricity charges & RM 110 \\
\hline 9. Char produced per year per unit & approximately 19 tons \\
\hline $\begin{array}{l}\text { 10. Cost of biochar (RM/MT) produced with } \\
\text { UBRHG }\end{array}$ & RM1100 - 1214.9/ton or \$333.3 - 368.2 /ton \\
\hline 11. Costs of RHC from UBRHG when RH is for free & RM 686/ton or $\$ 207.9 /$ ton \\
\hline 12. Annual sales out of char from UBRHG & RM 20900 - 23085 \\
\hline 13. Compare it to the market price & $\begin{array}{l}\text { Good agreement with Meyer et al. (2011) } \\
\text { with a pricing of RM 1100/ton }\end{array}$ \\
\hline 14. ROR on RH free basis & $72.4 \%-90.4 \%$ \\
\hline 15. ROR when RH is NOT for free & $0.044 \%-10.5 \%$ \\
\hline
\end{tabular}

operating at a power input of $155 \mathrm{~W}$ and a maximum flow rate of $1450 \mathrm{~m}^{3} / \mathrm{hr}$ regulated according to the air requirement. Building the upscale gasifier is simple and inexpensive. With the fairly satisfactory performance and ease of construction, the gasifier would find abundant avenues of applications in a rural setting for biochar production alongside thermal, mechanical and electrical energy delivery.

\section{Acknowledgements}

Financial support was provided by the Norwegian Research Council’s "Norway-Global partner” programme, Project 203901/H30 "Biochar on acidic agricultural lands in South-East Asia: Sequestering carbon and improving crop yield”.

\section{References}

[1] Leahy, S. (2013) Peak Water, Peak Oil... Now, Peak Soil? http://www.ipsnews.net/2013/05/peak-water-peak-oilnow-peak-soil/

[2] MacCarty, N., Ogle, D., Still, D., Bond, T. and Roden, C. (2008) A Laboratory Comparison of the Global Warming Impact of Five Major Types of Biomass Cooking Stoves. Energy for Sustainable Development, 12, 56-65. http://dx.doi.org/10.1016/S0973-0826(08)60429-9

[3] Johnson, M., Edwards, R., Alatorre Frenk, C. and Masera, O. (2008) In-Field Greenhouse Gas Emissions from Cookstoves in Rural Mexican Households. Atmospheric Environment, 42, 1206-1222. http://dx.doi.org/10.1016/j.atmosenv.2007.10.034

[4] Tye, Y.Y., Lee, K.T., Wan Abdullah, W.N. and Leh, C.P. (2011) Second-Generation Bioethanol as a Sustainable Energy Source in Malaysia Transportation Sector: Status, Potential and Future Prospects. Renewable \& Sustainable Energy Reviews, 15, 4521-4536. http://dx.doi.org/10.1016/j.rser.2011.07.099

[5] Oanh, N.T.K., Bich, T.L., Tipayarom, D., Manadhar, B.R., Prapat, P., Simpson, C.D. and Liu, L.-J.S. (2011) Characterization of Particulate Matter Emission from Open Burning of Rice Straw. Atmospheric Environment, 45, 493-502. http://dx.doi.org/10.1016/j.atmosenv.2010.09.023

[6] Darley, E.F., Burleson, F.R., Mateer, E.H., Middleton, J.T. and Osterli, V.P. (1966) Contribution of Burning of Agricultural Wastes to Photochemical Air Pollution. Journal of the Air Pollution Control Association, 11, 685-690. 
http://dx.doi.org/10.1080/00022470.1966.10468533

[7] Ballard-Tremeer, G. (1997) Emissions of Rural Wood-Burning Cooking Devices. http://www.ecoltdgroup.com/wp-content/uploads/2011/12/PhDThesis_GrantBallard-Tremeer.pdf

[8] Glaser, B., Lehmann, J. and Zech, W. (2002) Ameliorating Physical and Chemical Properties of Highly Weathered Soils in the Tropics With Charcoal—A Review. Biology and Fertility of Soils, 35, 219-230. http://dx.doi.org/10.1007/s00374-002-0466-4

[9] Carter, S., Shackley, S., Sohi, S., Suy, T. and Haefele, S. (2013) The Impact of Biochar Application on Soil Properties and Plant Growth of Pot Grown Lettuce (Lactuca sativa) and Cabbage (Brassica chinensis). Agronomy, 3, 404-418. http://dx.doi.org/10.3390/agronomy3020404

[10] Downie, A., Munroe, P., Cowie, A., Zwieten, V.L. and Lau, S.M.D. (2012) Biochar as a Geoengineering Climate Solution: Hazard Identification and Risk Management. Critical Reviews in Environmental Science and Technology, 42, 225-250.

[11] Johnson, M., Edwards, R., Ghilardi, A., Berrueta, V., Gillen, D., Frenk, C.A. and Masera, O. (2009) Quantification of Carbon Savings from Improved Biomass Cookstove Projects. Environmental Science and Technology, 43, 2456-2462. http://dx.doi.org/10.1021/es801564u

[12] Simon, G., Bumpus, A.G. and Mann, P. (2012) Win-Win Scenarios at the Climate-Development Interface: Challenges and Opportunities for Cookstove Replacement Programs through Carbon Finance. Global Environmental Change, 22, 275-287. http://dx.doi.org/10.1016/j.gloenvcha.2011.08.007

[13] Garrett, S., Hopke, P. and Behn, W. (2010) A Research Road Map: Improved Cook Stove Development and Deployment for Climate Change Mitigation and Women's and Children's Needs. http://www.geos.ed.ac.uk/homes/sshackle/BiocharStovesInnovation.pdf

[14] Apaydın-Varol, E. and Pütün, A.E. (2012) Preparation and Characterization of Pyrolytic Chars from Different Biomass Samples. Journal of Analytical and Applied Pyrolysis, 98, 29-36. http://dx.doi.org/10.1016/j.jaap.2012.07.001

[15] Belonio, A.T. (2005) Rice Husk Gas Stove Handbook. Appropriate Technology Center of the Department of Agricultural Engineering and Environmental Management, College of Agriculture, Central Philippine University, Iloilo City, Philippines. http://bioenergylists.org/stovesdoc/Belonio/Belonio_gasifier.pdf

[16] Panwar, N.L. and Rathore, N.S. (2008) Design and Performance Evaluation of a 5 kW Producer Gas Stove. Biomass and Bioenergy, 32, 1349-1352. http://dx.doi.org/10.1016/j.biombioe.2008.04.007

[17] Saravanakumar, A., Haridasan, T.M., Reed, T.B. and Bai, R.K. (2007) Experimental Investigation and Modelling Study of Long Stick Wood Gasification in a Top Lit Updraft Fixed Bed Gasifier. Fuel, 86, 2846-2856. http://dx.doi.org/10.1016/j.fuel.2007.03.028

[18] Zainal, Z.A., Rifau, A., Quadir, G.A. and Seetharamu, K.N. (2002) Experimental Investigation of a Downdraft Biomass Gasifier. Biomass and Bioenergy, 23, 283-289. http://dx.doi.org/10.1016/S0961-9534(02)00059-4

[19] Kaupp, A. (1984) Gasification of Rice Hull: Theory and Praxis. Federal Republic of Germany: GATE/GTZ, 303 p. http://dx.doi.org/10.1007/978-3-322-96308-6

[20] ASTM D1762-84 (2013) Standard Test Method for Chemical Analysis of Wood Charcoal. ASTM International, West Conshohocken. http://www.astm.org/Standards/D1762.htm

[21] Anon (1983) Simple Technologies for Charcoal Making. FAO Forestry Paper, FAO, Rome, 4.

[22] Buckee, G. (1994) Determination of Total Nitrogen in Barley, Malt and Beer by Kjeldahl Procedures and the Dumas Combustion Method. Journal of the Institute of Brewing, 100, 57-64.

[23] Enders, A., Hanley, K., Whitman, T., Joseph, S. and Lehmann, J. (2012) Characterization of Biochars to Evaluate Recalcitrance and Agronomic Performance. Bioresource Technology, 114, 644-653. http://dx.doi.org/10.1016/j.biortech.2012.03.022

[24] Hensley, M., Gu, S. and Ben, E. (2011) Biochar Production Potential in Ghana-A Review. Renewable \& Sustainable Energy Reviews, 15, 3539-3551. http://dx.doi.org/10.1016/j.rser.2011.05.010

[25] Garcia-Bacaicoa, P., Bilbao, R., Arauzo, J. and Salvador, M.L. (1994) Scale-Up of Downdraft Moving Bed Gasifiers $(25-300 \mathrm{~kg} / \mathrm{h})$-Design, Experimental Aspects and Results. Bioresource Technology, 48, 229-235. http://dx.doi.org/10.1016/0960-8524(94)90151-1

[26] Agrafioti, E., Bouras, G., Kalderis, D. and Diamadopoulos, E. (2013) Biochar Production by Sewage Sludge Pyrolysis. Journal of Analytical and Applied Pyrolysis, 101, 72-78. http://dx.doi.org/10.1016/j.jaap.2013.02.010

[27] Wiedner, K., Rumpel, C., Steiner, C., Pozzi, A., Maas, R. and Glaser, B. (2013) Chemical Evaluation of Chars Produced by Thermochemical Conversion (Gasification, Pyrolysis and Hydrothermal Carbonization) of Agro-Industrial Biomass on a Commercial Scale. Biomass and Bioenergy, 59, 264-278.

http://dx.doi.org/10.1016/j.biombioe.2013.08.026 
[28] Duku, M.H., Gu, S. and Hagan, E.B. (2011) Biochar Production Potential in Ghana-A Review. Renewable \& Sustainable Energy Reviews, 15, 3539-3551. http://dx.doi.org/10.1016/j.rser.2011.05.010

[29] Maschio, G., Koufopanos, C. and Lucchesi, A. (1992) Pyrolysis, a Promising Route for Biomass Utilization. Bioresource Technology, 42, 219-231. http://dx.doi.org/10.1016/0960-8524(92)90025-S

[30] Maiti, S., Dey, S., Purakayastha, S. and Ghosh, B. (2006) Physical and Thermochemical Characterization of Rice Husk Char as a Potential Biomass Energy Source. Bioresource Technology, 97, 2065-2070. http://dx.doi.org/10.1016/j.biortech.2005.10.005

[31] Nsamba, H., Hale, S., Cornelissen, G. and Bachmann, R. (2014) Improved Gasification of Rice Husks for Optimized Biochar Production in a Top Lit Updraft Gasifier. Journal of Sustainable Bioenergy Systems, 4, 225-242. http://dx.doi.org/10.4236/jsbs.2014.44021

[32] Galinato, S.P., Yoder, J.K. and Granatstein, D. (2011) The Economic Value of Biochar in Crop Production and Carbon Sequestration. Energy Policy, 39, 6344-6350. http://dx.doi.org/10.1016/j.enpol.2011.07.035

[33] Luoga, E., Witkowski, E.T. and Balkwill, K. (2000) Economics of Charcoal Production in Miombo Woodlands of Eastern Tanzania: Some Hidden Costs Associated with Commercialization of the Resources. Ecological Economics, 35, 243-257. http://dx.doi.org/10.1016/S0921-8009(00)00196-8

[34] Roberts, K.G., Gloy, B.A., Joseph, S., Scott, N.R. and Lehmann, J. (2010) Life Cycle Assessment of Biochar Systems: Estimating the Energetic, Economic, and Climate Change Potential. Environmental Science \& Technology, 44, 827833. http://dx.doi.org/10.1021/es902266r 